\title{
Klinikailag néma cerebrális iszkémia kialakulása pitvarfibrilláció katéterablációja során
}

\author{
Csanádi Zoltán \\ Debreceni Egyetem ÁOK, Kardiológiai Intézet, Debrecen \\ Levelezési cím: Prof. dr. Csanádi Zoltán, 4032 Debrecen, Móricz Zs. krt. 22. E-mail: drcsanadi@hotmail.com
}

\begin{abstract}
A pitvarfibrilláció katéterablációs kezelését követően detektálható, panaszt vagy tünetet nem okozó, „néma” cerebrális iszkémia az utóbbi 7-8 évben került az érdeklődés homlokterébe. Intézetünkben 2010-ben kezdtük el a jelenség szisztematikus vizsgálatát, ettől kezdve rutinszerüen használtuk a transcranialis Doppler és az intrakardiális echotechnikákat a PF-ablációk során képződő agyi mikroembólusok detektálására. Az alábbiakban a bal pitvari ablációk kapcsán megfigyelhető cerebrális mikroembolizáció kérdéskörét tekintem át, elsősorban saját eredményeink alapján.

Kulcsszavak: pitvarfibrilláció, néma cerebrális iszkémia, transcranialis Doppler, mikroembolizáció

\section{Mechanism of silent cerebral ischemia during catheter ablation of atrial fibrillation}

Silent cerebral ischemia detected after atrial fibrillation ablation has been studied intensively through the last 7-8 years. We have been studying this phenomenon at our Institute since 2010 with a systematic use of transcranial Doppler and intracardiac echocardiography to detect cerebral microembolisation during atrial fibrillation ablations. Herein, I review available data on cerebral microembolization in this context, mainly relying on the results of our group.
\end{abstract}

Keywords: atrial fibrillation, silent cerebral ischemia, transcranial Doppler, microembolisation

\section{Bevezetés}

A pitvarfibrilláció (PF) transzkatéteres kezelésének egyik legrettegettebb szövődménye a klinkailag manifeszt stroke/TIA. Az ablációs eljárás során a bal pitvari endothelium a PV-szájadékok körül nagy területen sérül az energialeadás következményeként olyan betegeken, akiknél a tromboembóliás kockázat szívritmuszavarukból eredően egyébként is magasabb az egészségesekhez képest. A transzszeptális katéterezés, a bal pitvarba vezetett eszközök révén koagulum, szövettermékek, levegő kerülhet a szisztémás keringésbe, ami szintén a cerebrális embolizáció forrása lehet (1). Különböző centrumok közlése alapján a manifeszt, klinikai cerebrális esemény előfordulása az $5 \%$ (2) és a $0 \%$ között szór (3). Általánosságban elmondható, hogy a PF-abláció bevezetése óta eltelt másfél évtizedben a beavatkozások cerebrovaszkuláris kockázata elsősorban a periprocedurális antikoagulálási protokoll változásának köszönhetően folyamatosan csökken (4). Egyre több centrumban végzik a beavatkozást megszakítás nélküli KVA-terápia, újabban direkt orális antikoaguláns mellett az ablációk alatt erőteljes iv. heparinizálással (legalább 300 sec feletti ACT-célérték), ami a legutóbbi ajánlásokban is megfogalmazódott (5).

A manifeszt cerebrális embolizáció előfordulásának említett csökkenése mellett aggasztó jelenség a néhány éve felismert klinikailag néma cerebrális iszkémia (Silent Cerebral Ischemia=SCl) gyakori előfordulása. Elsőként Schwartz (6) számolt be arról, hogy PF-ablációt követö 48 órán belül elvégzett diffúziós MR (DWMRI: Diffusion-Weighted Magnetic Resonance Imaging) vizsgálattal a betegek egy részében új, az abláció előtt végzett vizsgálattal még nem látható, általában 10 mm-nél kisebb, többnyire a fehér állományra lokalizálódó iszkémiás léziók mutathatók ki, amelyek semmiIyen tünetet vagy neurológiai vizsgálattal kimutatható eltérést nem okoznak (1. ábra). Későbbi vizsgálatok ezt a jelenséget a betegek 5-40\%-ában írták le (7-13) és 


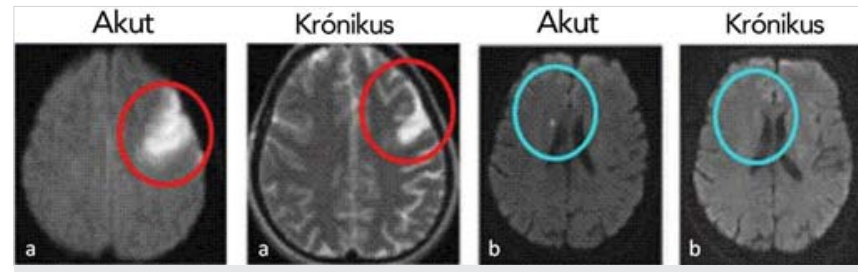

1. ÁBRA. Klinikailag manifeszt stroke (bal oldal) és néma iszkémiás lézió ( $\mathrm{SCl}=$ silent cerebral ischaemia) képe diffúziós mágneses magrezonancia vizsgálattal (DW-MRl=diffusion weighted magnetic resonance imaging) az akut és krónikus szakban. A néma agyi léziók a stroke-hoz viszonyítva kisebb ( $<10 \mathrm{~mm}$ ), többnyire a fehérállományra lokalizálódó elváltozások, amelyek néhány hét után méretükben csökkennek vagy eltünnek

az is egyértelművé vált, hogy a gyakoriság összefügg az alkalmazott ablációs technikával, legmagasabbnak a fázisos rádiófrekvenciás (RF) abláció során találták. Bár az $\mathrm{SCl}$ jelentősége egyértelmüen továbbra sem tisztázott, nem zárható ki, hogy a néma agyi infarktusok a posztoperatív kognitív funkció romlásához is vezethetnek.

A néma agyi léziók kimutatásának „gold-standard” vizsgálataként ugyan a DW-MRI-t tartják számon, a módszer nem szolgáltat adatot az embolizáció keletkezési mechanizmusáról: milyen természetű embólusok, a beavatkozás melyik szakaszában keletkeznek, kialakulásuk az abláció alatti energiaközlés milyen biofizikai paramétereivel hozható összefüggésbe. Ezzel szemben az a. cerebri mediaban megjelenő mikroembólus szignálok (MES: microembolic Signal) Transcraniális Dopplerrel (TCD) történő detektálása alkalmas a cerebrális mikroembolizáció valós idejü („real-time”) megítélésére (2. ábra) a PF transzkatéteres kezelése során $(14,15)$. Kilicaslan és munkatársai voltak az elsők, akik TCD-monitorozást használtak PF-ablációk alatt, és ők mutatták ki, hogy irrigált RF használata során mindig keletkeznek mikroembólusok, ráadásul sokkal nagyobb számban, mint amit általában egy szívmütét kapcsán detektálnak (16). Azt is igazolták, hogy a MES-szám összefügg a beavatkozáshoz köthető stroke-esemé- nyekkel. Az említett munkacsoport a TCD mellett intrakardiális ultrahang (ICE=intracardiac echocardiography) segítségével szemikvantitatív skála alapján értékelte a bal pitvarban keletkező buborékok menynyiségét (3. ábra), amely korrelált a TCD-vel regisztrált MES-számmal. Egy másik vizsgálatban a holland Sauren és munkacsoportja három ablációs eszközt hasonlított össze a TCD-vel intraprocedurálisan keletkező MES-számok alapján: a fokális RF, az irrigált RF, illetve a cryoballon (CB) katétert. Eredményeik alapján a mikroembólus-képződés mértéke szintén függött az alkalmazott katéteres technikától; a legbiztonságosabbnak a CB bizonyult (17).

Intézetünkben 2010-ben kezdtük el a PF-abláció kapcsán kialakuló néma cerebrális embolizáció jelenségének szisztematikus vizsgálatát. Ettől kezdve rutinszerüen használtuk a TCD- és ICE-technikákat a PF-ablációk során képződő agyi mikroembólusok detektálására. Betegeink egy csoportjában cerebrális DW-MRI-vizsgálatokat is végeztünk közvetlenül az abláció előtt és azt követően. Ez teremtette meg annak a lehetőségét, hogy 1. összehasonlítsuk a néma cerebrális iszkémia incidenciáját különböző PF-ablációs módszerek mellett;

2. értékeljük az ablációs technológiai fejlesztések és metodikai változtatások cerebrális mikroembolizációra kifejtett hatását;

3. információt gyűjtsünk a mikroembólusok fizikai természetéről, kialakulásuk mechanizmusáról. Az alábbiakban ezeknek a vizsgálatainknak legfontosabb megállapításait foglaljuk össze.

\section{Saját vizsgálataink néma cerebrális iszkémia kimutatására PF-abláció kapcsán}

Betegek és módszer

A vizsgálatokba paroxizmális vagy perzisztáló PF miatt egymás után katéterablációra kerülő betegeket vontunk be, amennyiben vállalták a TCD-monitorozást az ablációs beavatkozás teljes időtartama alatt. Az ablációk során valamennyi tüdő-véna ( $P V=$ pulmonary vein) teljes elektromos izolálása volt a cél. Ennek elérésére egyszerűsített „single shot” ablációs technikákat hasz-
Nincs mikroembólus

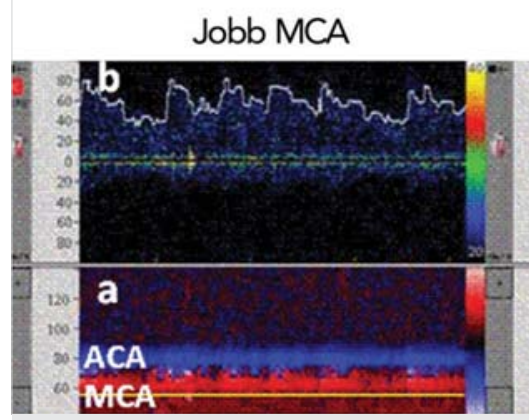

Bal MCA

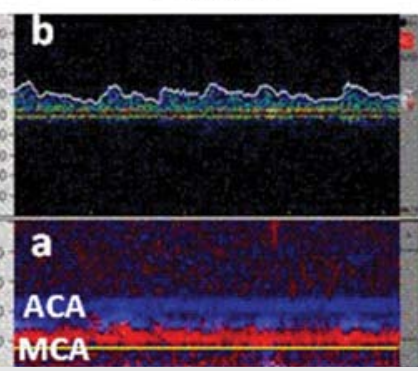

Mikroembólus szignálok (MES)

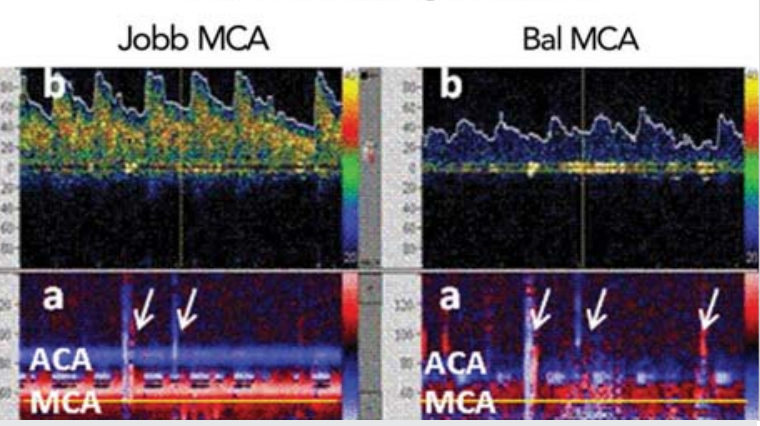

2. ÁBRA. Transcranialis Doppler-görbék az arteria cerebri media (MCA) bilaterális monitorozása során alapállapotban (bal oldali panel), illetve mikroembólus-szignálok megjelenésekor a nyilakkal jelzett helyen (jobb oldali panel) 
náltunk: cryoballont vagy fázisos RF-ablációr a körkörös multipoláris ablációs katéterrel (PVAC=Pulmonary Vein Ablation Catheter). Az ablációs technikákat korábban részletesen leírtuk $(18,19)$.

A mikroembolizáció követésére multifrekvenciás Doppler-készüléket használtunk (Multi Dop T-digital, DWL, QL software 2.8), amivel nemcsak az a. cerebri medián (MCA=middle cerebreal artery) áthaladó mikroembólusok számát tudtuk meghatározni, de azok szolid partikukum vagy gázbuborék jellege is elkülöníthető. $A z$ artefaktumok és a valódi cerebrális mikroembólusok elkülönítésében az eszköz érzékenysége 100\%, fajlagossága 99,3\%, a gáz és szolid mikroembólusokat 96,7\% specificitással különíti el (20). A transzducert egy speciális fejpánt rögzíti a halántékhoz. Igyekeztünk mindkét oldalon monitorozni az arteria cerebri mediát a transzszeptális szúrástól kezdve a bal pitvarban töltött egész idő alatt. Az irányelvekben meghatározott TCD-beállításokat használtuk (20): 45-55 mm közötti mélység, $8 \mathrm{~mm}$ sample volume, 60-10 mW közötti erősítés (21). Méréseink során regisztráltuk, hogy a beavatkozás során milyen arányban képződnek gáz, illetve szolid típusú mikroembólusok (2. ábra).

A MES-okat külön-külön számoltuk a beavatkozás egyes szakaszai során:

- transzszeptális punkció: ez a szakasz a fossa ovalis sikeres punkciója utáni 30 másodpercet foglalta magában.

- PV-angiográfia: a PV-k vizualizására használt kontrasztanyag beadásának ideje.

- Energiaközlés: ez a szakasz az energiaközlés kezdetétől a befejezés utáni 15. másodpercig tartott.

- Katétermanipuláció ideje: a beavatkozás egyéb szakaszait foglalta magában, amelynek során a fenti manőverek egyike sem zajlott.

A beavatkozások alatt a TCD-detekció mellett ICE segítségével is monitoroztuk a bal pitvari buborékképződést. Irodalmi adatoknak megfelelően a buborékképződés mértékét egy szemikvantitatív skálán fejeztük ki (16). „Kevésnek” tartottuk a buborékképződést, ha azok kis számban, izoláltan fordultak elő a bal pitvarban. A „közepesen sok” kategóriát akkor használtuk, ha a buborékok nagyobb mennyiségben és folyamatosan jelentek meg, de még nem alkottak konglomerá- tumot. „Sok”-nak tekintettük azt a folyamatosan, nagy számban képződő buborékmennyiséget, ahol a buborékok sürün egymás mellett, egymáshoz tapadva konglomerátumot képeztek (3. ábra).

A fent leírtak szerint végzett ablációk és mikroembolizáció detekciós metodikákra alapozva az alábbi összehasonlításokat és elemzéseket végeztük:

1. A CB- és PVAC-ablációk során mérhető mikroembólus szignálok (MES) számát úgy, hogy PVAC-ablációk alatt kétféle intraprocedurális heparinizációs protokollt alkalmaztunk egy minimum 250 sec feletti (PVAC) és egy $320 \mathrm{sec}$ feletti (PVAC magas ACT) aktivált koagulációs idő (ACT) elérésére törekedve. A vizsgálatok kitértek a MES természetének (szolid/ gáz) és az mikroembólusok kialakulásának ütemére az abláció különböző fázisai alatt. Szintén elemeztük a 2 intraoperatívan használható módszer, a TCD és az ICE által detektált mikroembolizáció összefüggését.

2. A fázisos RF-ablációk során talált kezdetben tapasztalt gyakori cerebrális léziók hátterében preklinikai vizsgálatok arra utaltak, hogy a PVAC elektródái között kialakuló magas áramsürűség következtében létre jövő hőmérsékleti csúcsok okozta mikroembólus képződés áll a léziók hátterében $(22,23)$. Klinikai eredmények, ezzel összhangban azt igazolták, hogy a PVAC 1. és 10. elektródján egyidejüleg alkalmazott RF-közlést kizáró ablációs protokoll mellett kevesebb az SCl előfordulása $(24,25)$. Mindezek alapján, a 10 elektróda mindegyikén rutinszerüen alkalmazott szimultán energialeadás gyakorlata változott: csak olyan esetben került rá sor, amikor az elektródák pozícióját átvilágítással ellenőrizve, azok nem kerültek közeli kontaktusba egymással (4. ábra). Mindezek alapján, összehasonlítottuk a mikroembolizációt azokban a kezdeti eseteinkben, amikor még a fent leírt elektróda-interakció jelensége ismeretlen volt és elkerülésére semmilyen erőfeszítést nem tettünk (1. csoport); amikor szimultán energiaközlést csak az átvilágítás alapján megfelelőnek ítélt elektróda-pozíciók esetén végeztünk (2. csoport); a fázisos RF-ablátor továbbfejlesztett softwarének használatával, ami a PVAC-körfogat széli részein elhelyezett 1-es és 10-es elektródákon (amelyek között a legnagyobb

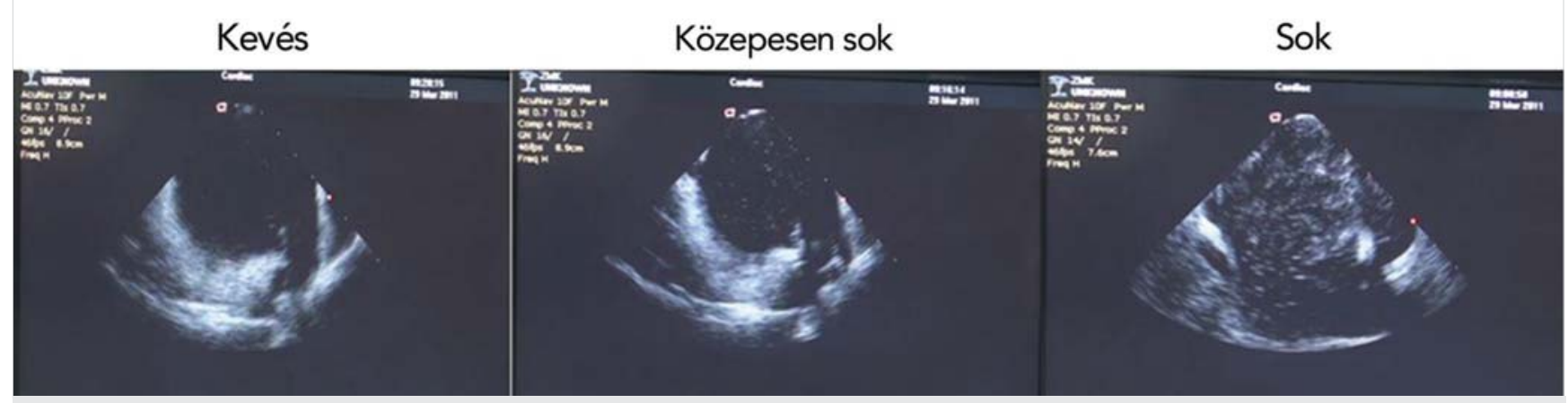

3. ÁBRA. A buborékképződés osztályozása intrakardiális echokardiográfiával 


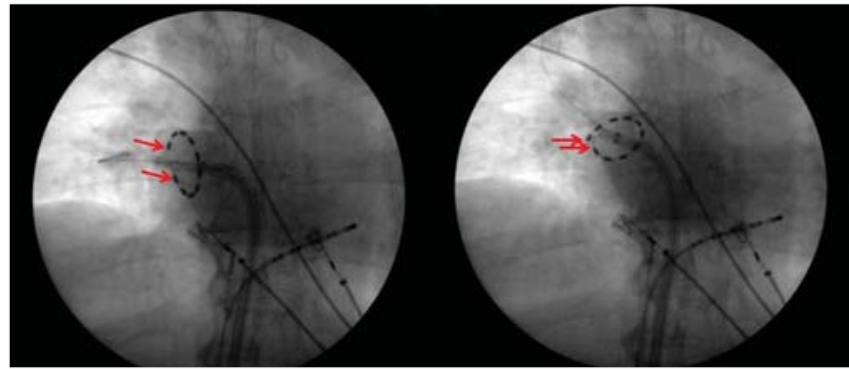

4. ÁBRA. A PVAC-elektróda pozíciók megítélése. A bal oldali képen biztonságos, a jobb oldalon túl közeli 1-10 elektróda helyzet (piros nyilak) látható

az interakció esélye) a szimultán RF-leadást nem teszi lehetőve (3. csoport).

3. Vizsgáltuk a mikroembolizáció összefüggését az abláció alatti alapritmussal (sinus versus PF) és az abláció helyével (a $4 \mathrm{PV}$ valamelyike).

4. Elemeztük az abláció biofizikai paraméterei és a mikroembólus-képződés mértékének kapcsolatát.

5. Korlátozott számú (27) betegen értékeltük a fázisos RF-abláció előtt és után végzett DW-MRI-vizsgálatok alapján igazolt új keletũ SCl és az ablációk alatt detektált mikroembólus számok közötti korrelációt.

\section{Fontosabb megállapításaink}

Kimutattuk, hogy a kezdetben alkalmazott fázisos RFablációs technika és a korábbi Genius RF-generátor használata szignifikánsan több mikroembólus-képződéssel jár, mint a CB-abláció (5. ábra). Ezen számottevően az sem változtat, ha az ACT-célértéket $320 \mathrm{sec}$ fölé emeljük a PVAC-beavatkozások során. A mikroembólusok CB-abláció alatt egyenletesen képződnek, ezzel szemben fázisos RF-ablációk során képződésük az energialeadás tartamára koncentrálódik (6. ábra). Bármely technika használatakor a keletkező mikroembólusok túlnyomóan gáztermészetüek (7. ábra). Igazoltuk, hogy a TCD alkalmas a MES-ek regisztrálására,

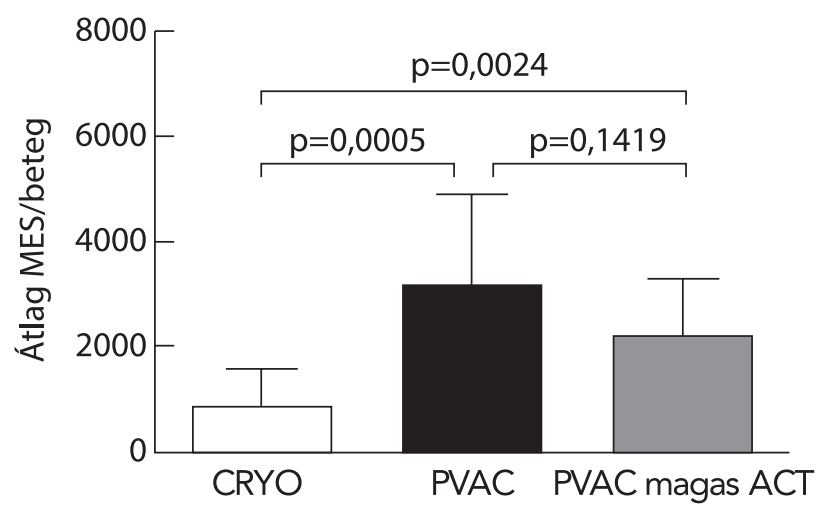

5. ÁBRA. A mikroembólusok száma a három ablációs csoportban. CRYO: Cryoballon; PVAC: Pulmonalis vénaablációs-katéter; $A C T$ : aktivált alvadási idő; MES: mikroembólus szignál

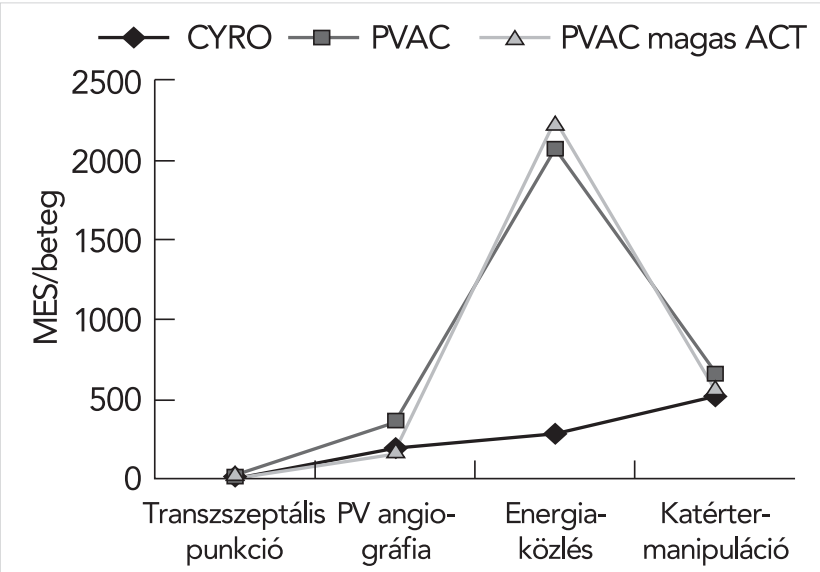

6. ÁBRA. A mirkoembólus-képződés üteme az egyes ablációs szakaszokban. PVAC-ablációk során kiugró csúcs látható az energiaközlés alatt, míg CB alkalmazásával egyenletes ütemű MES-képződés figyelhető meg a procedúra alatt (rövidítés ld. előző ábra)

a mikroembolizáció intenzitása szorosan összefügg az ICE-vel detektált buborékképződés mértékével (8. ábra) (26).

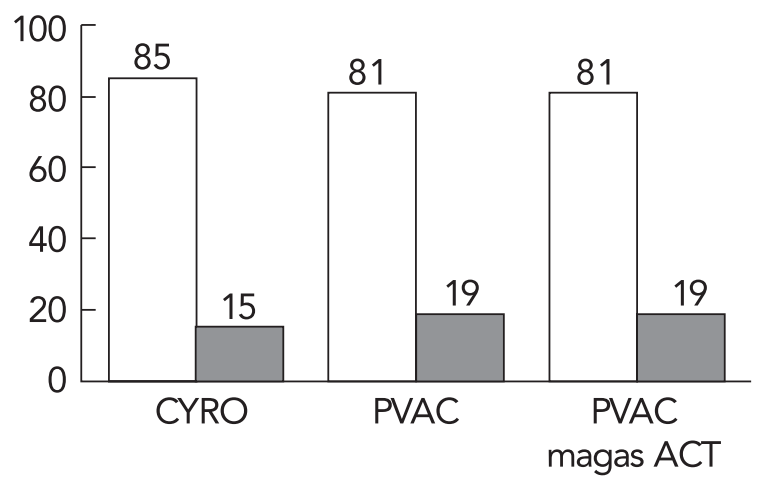

Gázembólusok (\%) $\square$ Szolid embólusok (\%)

7. ÁBRA. Gáz- és szolid embólusok aránya a három ablációs csoportban. ACT: aktivált alvadási idő

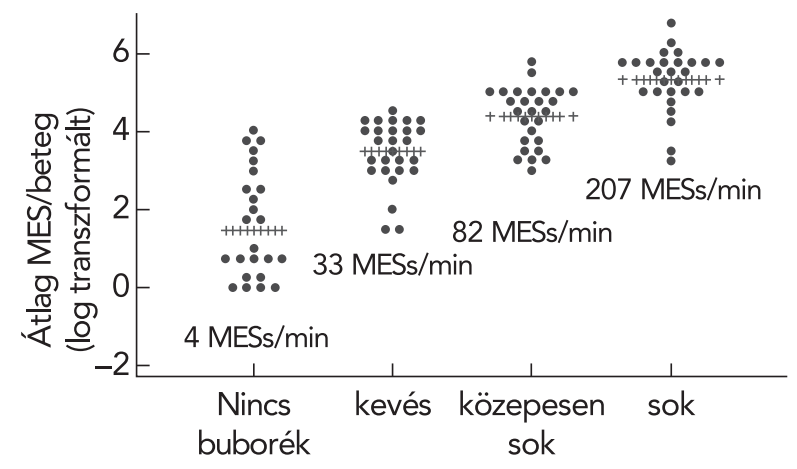

$p<0,001$ Buborékképződés mértéke az ICE képen

8. ÁBRA. ICE - TCD-korreláció. ICE: Intrakardiális echokardiográfia; TCD: Transcranialis Doppler; MES: mikroembólus szignál 

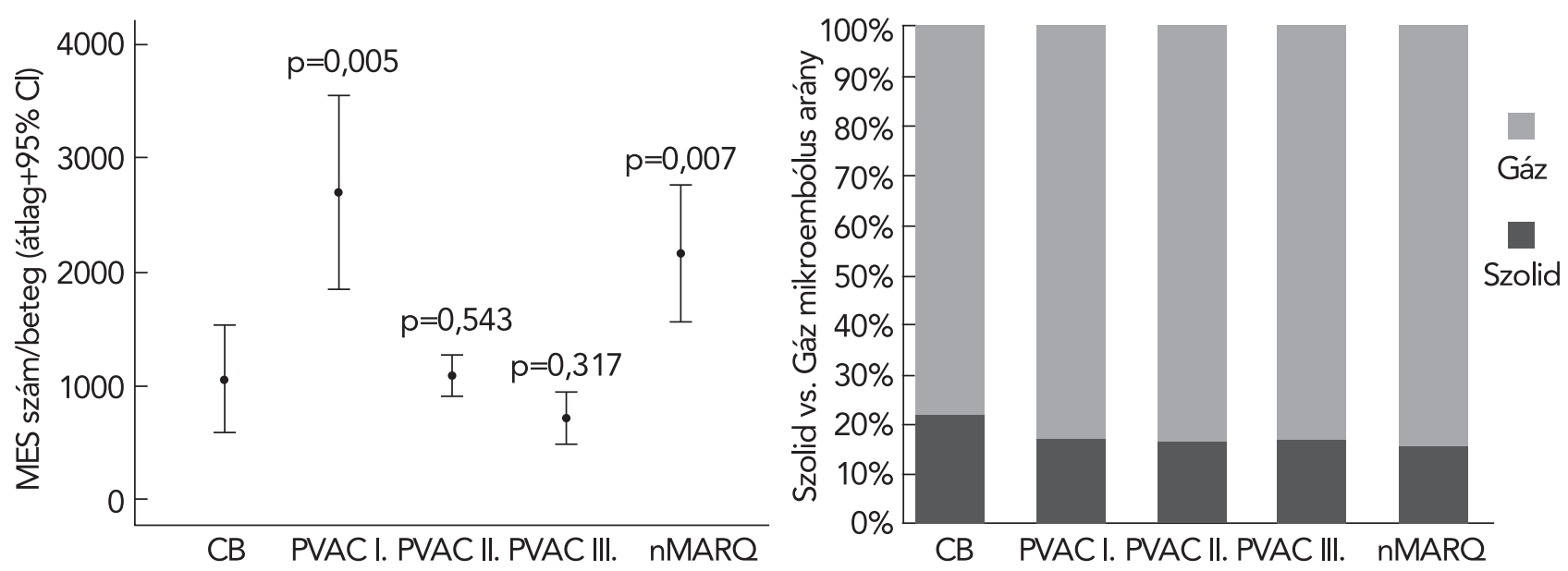

9. ÁBRA. Bal oldali panel: Az arteria cerebri mediaban detektált átlag mikroembólus-szám az 5 különböző ablációs csoportban. A PVAC- és nMARQ-csoportokban mért átlag MES-számokat a CB-csoporthoz viszonyítottuk. Nem volt szignifikáns különbség a CB, PVAC II. $(p=0,543)$ és PVAC III. csoport ( $p=0,317)$ között az átlagos összes MES-számban. Szignifikánsan több összesített MES képződött a PVAC I. ( $p=0,005)$ és nMARQ-csoportban ( $p=0,007)$. Jobb oldali panel: A szolid/gáz mikroembólusok mindaz 5 terápiás csoportban hasonlóan, közel $20 \%$ szolid-80\% gáz arányban oszlottak el (Rövidítések, mint az előző ábrákon)

Bizonyítottuk, hogy a fázisos RF-ablációkkal kapcsolatban az elmúlt években bevezetett változások, elsősorban a PVAC-elektróda interakciók kiküszöbölésére, valamint a Genius generátorban végrehajtott software módosítások hatására a TCD-vizsgálattal detektált MES-számok szignifikánsan csökkentek a CB-ablációk során mért értékekhez hasonló szintre. Az új, multipoláris, körkörös, irrigált ablációs katéter, az nMARQ alkalmazása ugyanakkor magas, a régi fázisos RF-ablációs technikával regisztráltakhoz hasonló MES-képződéssel jár (27) (9. ábra).

Megállapítottuk, hogy fázisos RF-ablációk alatt a mikroembolizációt fokozza a minél több aktív elektróda,

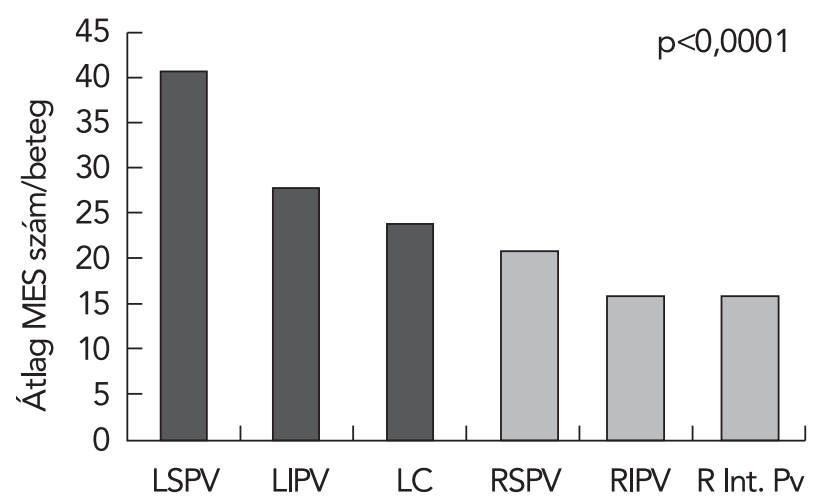

10. ÁBRA. Átlagos mikroembólus-szám/beteg a különböző tüdővénák ablációjakor. A baloldali tüdővénák ablációja alatt szignifikánsan több mikroembólus képződött. MES: mikroembólus szignál; LSPV: bal felső tüdővéna (left superior pulmonary vein); LIPV: bal alsó tüdővéna (left inferior pulmonary vein); LC: bal közös szájédék (left common); RSPV: jobb felső tüdővéna (right superior pulmonary vein); RIPV: jobb alsó tüdővéna (right inferior pulmonary vein); R Int. PV: jobb intermedier ág a magasabb leadott összteljesítmény, továbbá mind az alacsonyabb (45-55 ${ }^{\circ} \mathrm{C}$ közötti tartományba eső) átlaghőmérséklet, mind pedig a $62{ }^{\circ} \mathrm{C}$ feletti hőmérsékleti túllövés előfordulása. Ugyancsak magasabb MES-számot regisztráltunk a PVAC E1-10 elektródáinak szimultán aktivációja esetén annak ellenére, hogy azok helyzetét és egymástól való távolságát átvilágítással ellenőriztük az energiaközlés előtt és időről időre az alatt is. A szöveti kontaktus jellemzésére megalkotott templát deviációs és respiráció okozta kontaktus hiba score vizsgálatával bizonyítottuk, hogy multipoláris ablációk esetén a nem optimális elektróda-szövet kapcsolat a mikroembólusok képződés fontos forrása (28).

Kimutattuk, hogy fázisos RF-ablációk alatt a bal oldali PV-k kezelése során több mikroembólus képződik (10. ábra). Az energiaközlések alatti szívritmus szintén befolyásolja a mikroembólusok képződését: PF-ben szignifikánsan magasabb hőmérsékletet és szignifikánsan alacsonyabb teljesítményt mértünk, mint SR-ben. (52,8 SD: $3,5^{\circ} \mathrm{C}$ PF alatti energiaközlések alatt vs. $51,3 \mathrm{SD}: 3,3{ }^{\circ} \mathrm{C}$ SR-ben; $\left.p<0,0001\right)(5$, 6) SD:1,6 W PF-ben vs. 6,2 SD:1,4 W SR-ban, unadjusted $p<0,0001$, robust unadjusted $p=0,0499$. Sinusritmusban, $56{ }^{\circ} \mathrm{C}$ felett kevesebb mikroembolizációval kell számolni. Ezzel szemben, $56^{\circ} \mathrm{C}$ hőmérséklet alatt a szívritmus a keletkező mikroembólusok számát nem befolyásolja (29).

Limitált betegszám mellett végzett vizsgálataink trendszintü kapcsolatot mutattak a DW-MRI vel igazolt SCl előfordulása és a bal pitvari ablációk alatt regisztrált összes mikroembólusszám között, a tüdővéna angiográfiák alatt detektált mikroembólusok száma ugyanakkor szignifikánsan prediktív volt a néma agyi iszkémia kialakulására (30). 


\section{Eredményeink klinikai implikációi}

\begin{abstract}
Vizsgálataink igazolták, hogy a TCD megbízható módszer a bal pitvari ablációk kapcsán keletkező agyi mikroembólusok kimutatására. Használatával képet kaphatunk a jelenség dinamikájáról, az embólusok szolid vagy gáztermészetéről, megítélhetjük az ablációs technika módosításaival elérhető eredményt. Bizonyítottuk, hogy a bal pitvari ablációk során elsősorban gázjellegü mikrobuborékok alakulnak ki, ezért önmagában az antikoagulációs protokoll a jelenséget csak korlátozottan képes befolyásolni. Kimutattuk, hogy a mikroembolizáció akár a teljes ablációs beavatkozás alatt, akár annak különböző fázisaihoz kapcsolódva erősen függ az ablációs technikától, annak változtatásai számottevően képesek befolyásolni. A biofizikai paraméterek az elektródaszövet kontaktussal összefüggésben befolyásolják a mikroembólusok képződését, jelentősége van továbbá a bal pitvaron belüli lokalizációnak és az aktuális ritmusnak. Az agyi DW-MRI-vizsgálattal kimutatott léziók és a TCD-vel detektált mikroembolizáció közötti összefüggés tisztázására nagyobb betegszám mellett további tanulmányok szükségesek. Az antiaritmiás gyógyszeres terápia máig megoldatlan problémái (31) felértékelik minden olyan kutatásnak a fontosságát, amellyel a katéteres alternatíva biztoságosabbá tehető.
\end{abstract}

\section{Irodalom}

1. Kok LC, Mangrum JM, Haines DE, et al Cerebrovascular complication associated with pulmonary vein ablation. J Cardiovasc Electrophysiol 2002; 13:764-767. https://doi.org/10.1046/j.1540-8167.2002.00764.x 2. Lee G, Sparks PB, Morton JB, et al. Low risk of major complications associated with pulmonary vein antral isolation for atrial fibrillation: results of 500 consecutive ablation procedures in patients with low prevalence of structural heart disease from a single center. J Cardiovasc Electrophysiol 2011; 22: 163-168. https://doi.org/ 10.1111/j.1540-8167.2010.01870.x 3. Hoyt H, Bhonsale A, Chilukuri K, et al. Complications Arising From Catheter Ablation of Atrial Fibrillation: Temporal Trends and Predictors. Heart Rhythm 2011; 8:1869-1874. https://doi.org/10.1016/j.hrthm.2011.07.025

4. Csanadi Z, Nagy-Baló E, Dank S, et al. Cerebrovascular Complications Related to Atrial Fibrillation Ablation and Strategies for Periprocedural Stroke Prevention. Cardiac Electrophysiol Clinics 2014; 6: 111-123. https://doi.org/10.1016/j.ccep.2013.10.003

5. Calkins H, Hindricks G, Cappato R, et al. 2017 HRS/EHRA/ECAS/APHRS/SOLAECE expert consensus statement on catheter and surgica ablation of atrial fibrillation: executive summary. J Interv Cardiol 2017, DOI 10.1007/s10840-017-0277-z

6. Schwarz N, Kuniss M, Nedelmann M, et al. Neuropsychological decline after catheter ablation of atrial fibrillation. Heart Rhythm 2010; 7 1761-1767. https://doi.org/10.1016/j.hrthm.2010.07.035

7. Herrera Siklódy C, Deneke T. Hocini M, et al. Incidence of asymptomatic intracranial embolic events after pulmonary vein isolation: comparison of different atrial fibrillation ablation technologies in a multicenter study. J Am Coll Cardiol 2011; 8: 681-688. https://doi.org/10.1016/j jacc. 2011.04.010

8. Gaita F Leclercq JF Schumacher B et al. Incidence of silent cerebra thromboembolic lesions after atrial fibrillation ablation may change according to technology used: comparison of irrigated radiofrequency, multipolar nonirrigated catheter and cryoballoon. J Cardiovasc Electrophysiol 2011; 22: 961-968. https://doi.org/ 10.1111/j.1540-8167.2011.02050. 9. Neumann T Kuniss M Conradi G, et al MEDAFI-Trial (Micro-embolization during ablation of atrial fibrillation): comparison of pulmonary vein isolation using cryoballoon technique vs. radiofrequency energy. Europace 2011; 13: 37-44. https://doi.org/10.1093/europace/euq303

10. Gaita F, Caponi D, Pianelli M, et al. Radiofrequency catheter ablation of atrial fibrillation: a cause of silent thromboembolism? Magnetic resonance imaging assessment of cerebral thromboembolism in patients undergoing ablation of atrial fibrillation. Circulation 2010; 122: 1667-1673. https://doi.org/10.1161/CIRCULATIONAHA.110.937953

11. Schrickel JW, Lickfett L, Lewalter T, et al. Incidence and predictors of silent cerebral embolism during pulmonary vein catheter ablation for at- rial fibrillation. Europace 2010; 12: 52-57. https://doi.org/ 10.1093/europace/eup350

12. Lickfett L, Hackenbroch M, Lewalter T, et al. Cerebral diffusion-weighted magnetic resonance imaging: a tool to monitor the thrombogenicity of left atrial catheter ablation. J Cardiovasc Electrophysiol 2006; 17 1-7. https://doi.org/10.1111/j.1540-8167.2005.00279x

13. Verma A, Debruyne P, Nardi S, et al. Evaluation and reduction of asymptomatic cerebral embolism in ablation of atrial fibrillation, but high prevalence of chronic silent infarction: results of the evaluation of reduction of asymptomatic cerebral embolism trial. Circ Arrhythm Electrophysio 2013; 6: 835-842. https://doi.org/10.1161/CIRCEP.113.000612

14. Borger MA, Peniston CM, Weisel RD, et al. Neuropsychologic impairment after coronary bypass surgery: Effect of gaseous microembol during perfusionist interventions. J Thorac Cardiovasc Surg 2001; 121 743-749. https://doi.org/10.1067/mtc. 2001.112526

15. Gaunt ME, Martin PJ, Smith JL, et al. Clinical relevance of intraoperative embolization detected by transcranial doppler ultrasonography during carotid endarterectomy: A prospective study of 100 patients. $\mathrm{Br} J$ Surg 1994; 81: 1435-1439. https://doi.org/10.1002/bjs.1800811009

16. Kilicaslan F, Verma A, Saad E, et al. Transcranial Doppler detection of microembolic signals during pulmonary vein antrum isolation: implications for titration of radiofrequency energy. J Cardiovasc Electrophysio 2006; 17: 495-501. https://doi.org/10.1002/bjs.1800811009

17. Sauren LD, Van Belle Y, De Roy L, et al. Transcranial measurement of cerebral microembolic signals during endocardial pulmonary vein isolation: Comparison of three different ablation techniques. J Cardiovasc Electrophysiol 2009; 20: 1102-1107. https://doi.org/10.1111/j.15408167.2009.01509x

18. Tóth Z, Nagy-Baló E, Kertész A, et al. Pitvarfibrilláció kezelése a pulmonalis vénák krioballon-izolációjával: Középtávú eredmények az első 55 beteg alapján. Orvosi Hetilap 2010; 151: 163-171.

19. Nagy-Baló E, Tint D, Beke I, Dévényi K, et al. A pitvarfibrilláció rádiófrekvenciás ablációs kezelése anatómiai tervezésü katéterekkel: rövidtávú eredmények az első 48 beteg alapján. Cardiologia Hungarica 2011; $41: 2-7$

20. Markus HS, Punter M. Can transcranial Doppler discriminate between solid and gaseous microemboli? Assessment of a dual-frequency transducer system. Stroke 2005; 36: 1731-1734. https://doi.org/10.1161/01. STR.0000173399.20127.b3

21. Ringelstein EB, Droste DW, Babikian VL, et al. Consensus on microembolus detection by TCD. International Consensus Group on Microembolus Detection. Stroke 1998; 29: 725-729. https://doi.org/10.1161/01. STR.29.3.725

22. Haines DE, Stewart MT, Dahlberg S, et al. Microembolism and catheter ablation I: a comparison of irrigated radiofrequency and multielectrode-phased radiofrequency catheter ablation of pulmonary vein ostia. Circ Arrhythm Electrophysiol 2013; 6: 16-22. https://doi.org/10.1161/ CIRCEP 111.973453

23. Haines DE, Stewart MT, Barka ND, et al. Microembolism and catheter ablation II: effects of cerebral microemboli injection in a canine model. Circ Arrhythm Electrophysiol 2013; 6: 23-30. https://doi.org/10.1161 CIRCEP.112.973461

24. Wieczorek M, Hoeltgen $R$, Brueck $M$. Does the number of simultaneously activated electrodes during phased RF multielectrode ablation of atrial fibrillation influence the incidence of silent cerebral microembolism? Heart Rhythm 2013; 10: 953-959. https://doi.org/10.1016/j. hrthm.2013.04.005

25. Wieczorek M, Lukat M, Hoeltgen R, et al. Investigation into causes of abnormal cerebral MRI findings following PVAC duty-cycled, phased RF ablation of atrial fibrillation. J Cardiovasc Electrophysiol 2013; 24 121-128. https://doi.org/10.1111/jce.12006

26. Nagy-Baló E, Tint D, Clemens M, et al. Transcranial Measurement Of Cerebral Microembolic Signals During Pulmonary Vein Isolation: A Comparison Of Two Ablation Techniques. Circulation Arrhythmia and Electrophysiology 2013; 6: 473-480. https://doi.org/10.1161/CIRCEP.112.971747.

27. Kiss A, Nagy-Baló E, Sandorfi G, et al. Cerebral microembolization during atrial fibrillation ablation: Comparison of different single-shot ablation techniques. International Journal of Cardiology 2014; 174: $276-$ 281. https://doi.org/10.1016/i.ijcard.2014.03.175

28. Nagy-Balo E, Kiss A, Condie C et al. Predictors of cerebral microembolization during phased radiofrequency ablation of atrial fibrillation analysis of biophysical parameters from the ablation generator. Heart Rhythm 2014; 11: 977-983. https://doi.org/10.1016/j.hrthm.2014.03.018 29. Nagy-Balo E, Kiss A, Condie C, et al. Predictors of Cerebral Microembolization during Phased Radiofrequency Ablation of Atrial Fibrillation: Role of the Ongoing Rhythm and the Site of Energy Delivery Pacing And Clinical Electrophysiology Pace 2014; 11: 977-983. https://doi. org/10.1111/pace.12454

30. Nagy-Baló E, Martirosyan M, Sándorfi G, et al. Cerebral micro-embolization during pulmonary vein isolation: relation to post-ablation silent cerebral ischemia. Cardiology Journal 2017; 24(3): 234-241. https://doi. org/10.5603/CJ.a2017.0030

31. Lengyel C, Varro A, Tabori K et al. Combined pharmacological block of $I_{K_{\text {}}}$ and $I_{k_{s}}$ increases short-term QT interval variability and provokes torsades de pointes. British Journal of Pharmacology (2007) 151, 941-951. 